
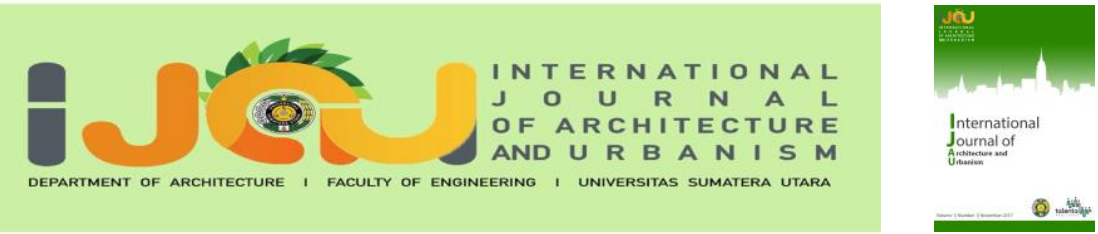

\title{
Eco Architecture on Design Creative Center for Children in Medan
}

\author{
Sonia Sabira Lubis ${ }^{1}$, Nelson M. Siahaan ${ }^{1}$ \\ ${ }^{1}$ Architecture Departement, Faculty of Engineering, Universitas Sumatera Utara, Medan, Indonesia
}

\begin{abstract}
Childhood is one phase of human that plays an important role for children, especially of the child's brain. Besides that, generals in this phase, the creativity and the character development of children also begin to form. Indonesia has diverse cultures, religions, and languages. Traditional games are also included in cultural diversity. But unfortunately, as the development of science and technology progresses like digital games, these games have gradually begun to extinct and is rarely played by children. The project tries to overcome the problem by designing a building that can become an educational and recreation area. The methodology of this project starts from conducting site selection by literature studies, then the design problem-solving phase, namely by searching ideas, collecting data, literature studies, observation studies, comparative studies. This research produces buildings that can respond to these problems by applying the concepts of ecology architecture to the design. The benefit of this design is that children are more familiar with traditional games and energy-efficient buildings.
\end{abstract}

Keywords: children, creative, ecological architecture, traditional games

\section{Introduction}

Childhood is a phase in a human growth that plays an important role for children, especially on the child's brain. Besides that, generals in this phase the creativity and the character development of children also begin to form. Creativity can be identified and fostered through proper education [1]. Indonesia has diverse cultures, religions, and languages. Traditional games also included in this cultural diversity. The fact is that children nowadays are less familiar with these from their regions. Parents no longer introduce traditional games to their children when they were young. Traditional games have lost their meaning, both philosophical and social.

This project is a recreational facility that aims to introduce traditional games, especially North Sumatra games. Presenting a space that is relevant to the function of the project and children nowadays but still does not eliminate the atmosphere and characteristics of its culture. The use of attractive colors is also chosen to attract the interest of children. This project is also expected to educate tourists from Medan and tourists visiting Medan.

\footnotetext{
*Corresponding author at:Department of Architecture, Faculty of Engineering, Universitas Sumatera Utara, Jalan Perpustakaan Gedung J07, Medan 20155, Indonesia

E-mail address: lubis_sonia@yahoo.com
} 


\section{Literature Review}

\section{Location and Site}

The project situated at Medan, Medan Petisah, North Sumatra. Medan Petisah is part of the WPP E development area which is intended for residential areas, offices, trade, conservation, recreation, golf courses, and City forests. The selection of a location for the design of the Children's Creative Center in Medan is based on this. A site is a strategic place because easy to approach. Not only that, but there are also many facilities around the site that can support the project. Access to the site is easy because it has various types of transportation passing by. A public and private vehicle can access this location through 8 routes (Figure 1).

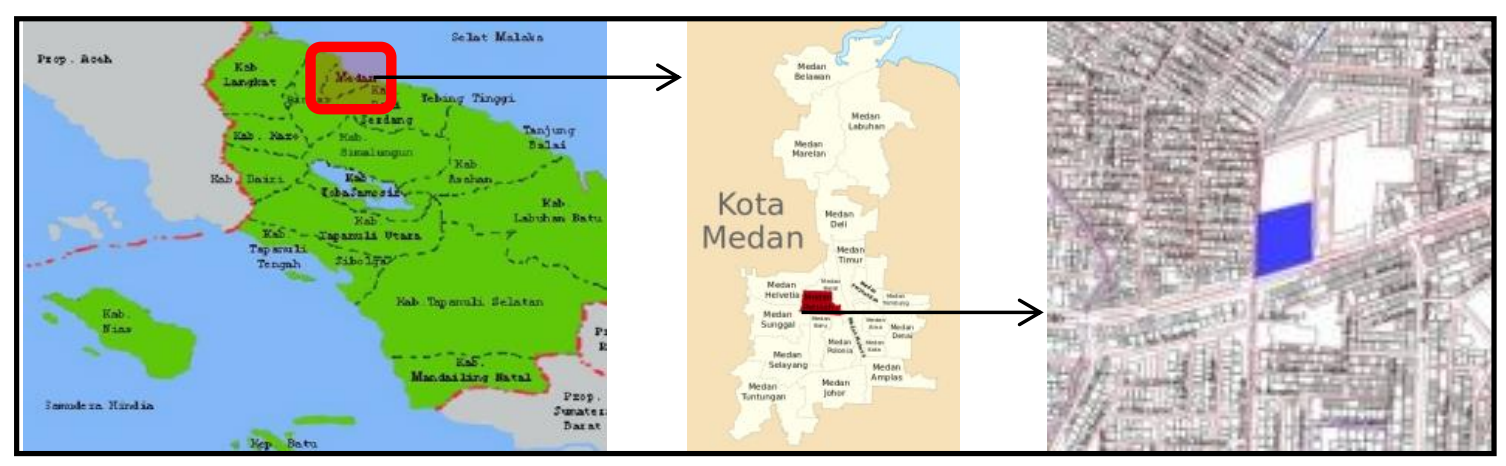

Figure 1. Project Location

\section{Theme Review}

In the design of the Children's Creative Center in Medan, it uses the theme of Ecological architecture. The ecological architecture consists of two words, Architecture and Ecology. The ecological architecture approach or eco-architectural design is not a specific concept of hi-tech building design, but a building design concept that emphasizes awareness and courage to decide it of building design that respects the importance of ecosystem sustainability in nature[2].

Eco-architecture does not determine what should happen in architecture because there is no characteristic that is binding as standard or standard size [3]. But it includes harmony between humans and nature. Eco-architecture also contains the dimensions of time, socio-cultural, space and building techniques [4]. So it can be concluded that ecological architecture is a science to create buildings that consider the existence and sustainability of living things and natural ecosystems and this design can also have a positive impact on its users.

Ecological architecture has several principles in its design, namely, From several them put forward by experts, it concluded that the Ecological architecture has principles in its design as follows: Saving natural energy sources, optimizing the use of material again,, paying attention to local ecosystems with long-term planning, the buildings must be responsive to the surrounding climate problems and existences, efficiency in water and electricity use, use of technology or environmentally friendly materials. 3R (Reuse, Reduce, Recycle). 


\section{Comparative Study}

The Human Body Museum has the concept which functions as a mediator between nature and the city. Stunning scenery and internal connections are all expressed by the shape of the Museum's shift. (Figure 2)

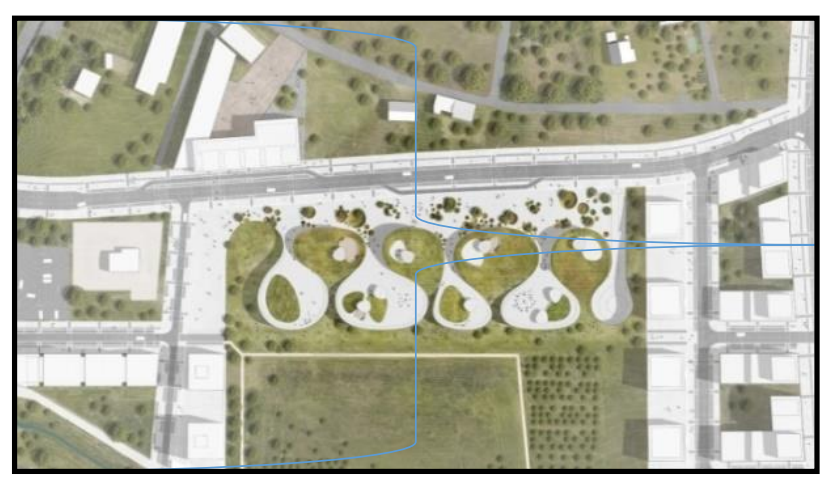

Figure 2 Human Body Museum Siteplan

Source:https://www.archdaily.com/450388/big-selected-to-design-human-body-museum-infrance accessed on March 27, 2018

The roof that applies the green roof concept serves as an ergonomic plant. Also, it can also be accessed by visitors to explore and express their bodies in various ways. From starting to relax, exercise and calm down. (Figure 3).

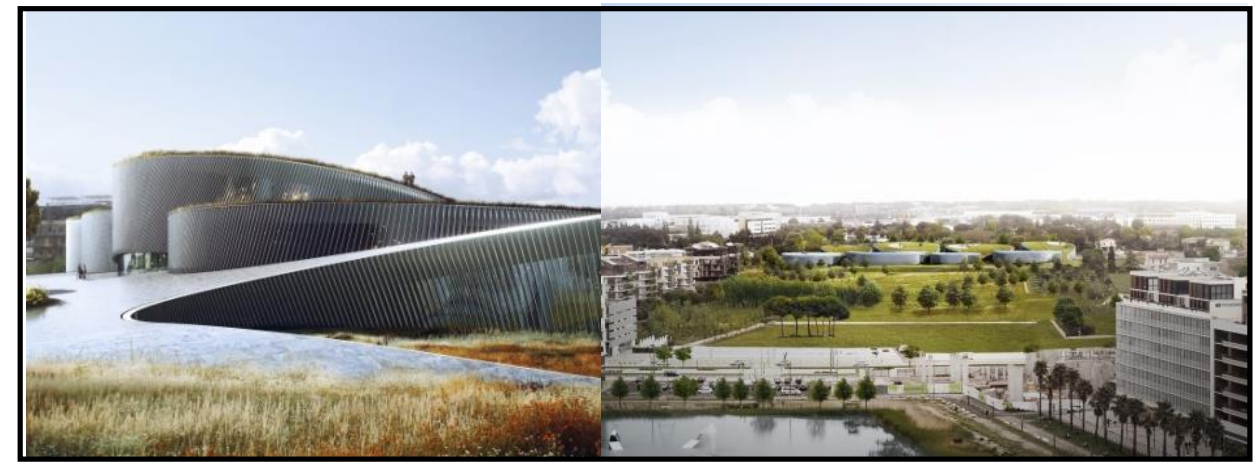

Figure 3. Human Body Museum Fasade

Source:https://www.archdaily.com/450388/big-selected-to-design-human-bodymuseum-in-france accessed on March 27, 2018 
The facades of the Museum of the Human Body are transparent, maximizing the visual and physical connection to the surroundings. On the sinuous facade that oscillates between facing North and South, East and West, the optimum louver orientation constantly varies, protecting sunlight, while also resembling the patterns of a human fingerprint - both unique and universal (Figure 4).

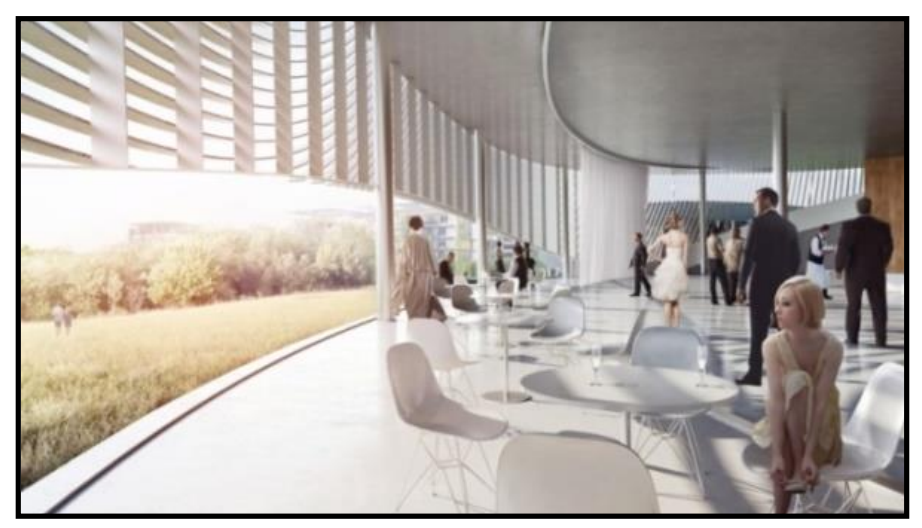

Figure 4. The optimal use of window Human Body Museum Source:https://www.archdaily.com/450388/big-selected-to-design-human-bodymuseum-in-france accessed on March 27, 2018

The Olomouc City Center for Ecological Activities has also a function as part of a project entitled "Slunakov, a facility for ecological activities - educational center", which is located northwest of Olomouc, in the Morava River valley. This facility is to be used to educate the public about the environment and its processes and to support the community's environmental awareness. This building is also used as an information center and entrance to the Litovelske Pomoravi Nature Protection Area (Figure 5).

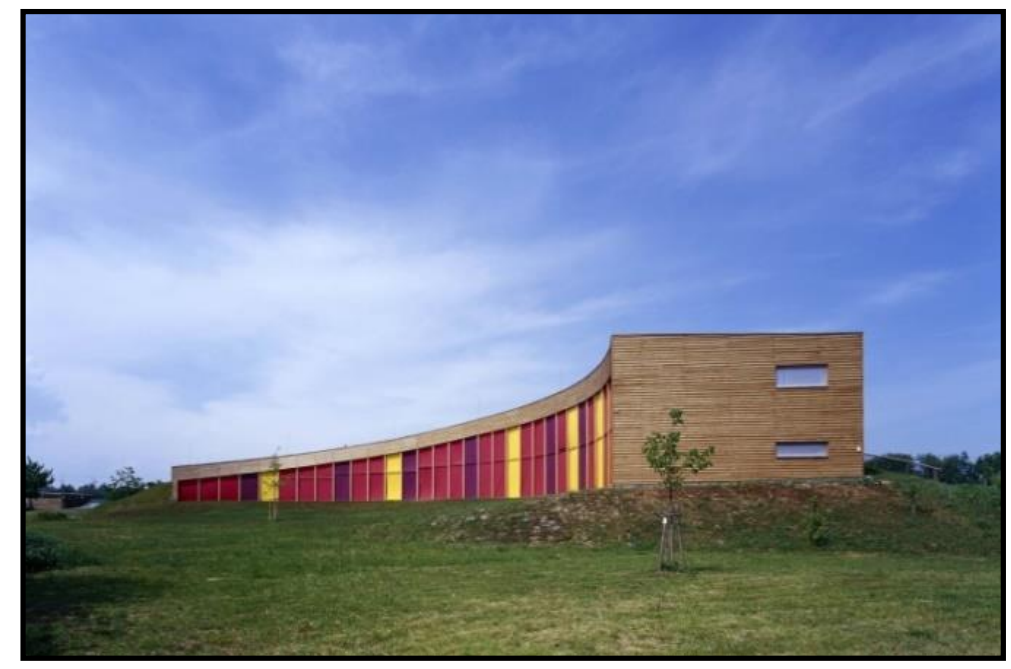

Figure 5. Slunakov Center for Ecological Activities Fasade

Source:https://www.archdaily.com/29349/slunakov-center-for-ecological-activitiesprojektil-architekti accessed on March 27, 2018

The building designed as a curved inhabitable land wave that fluently blends into the surrounding terrain and symmetrically follows the exact North-South axes.Architectural design uses the south orientation with the southern glass facade with movable sun blinds. Two recessed 
entrances situated on the northern side. The eastern side of the building symbolically ascends from the ground to enhance the display of the southwestern sunshine. on the roof using the green roof concept that makes the room inside it cooler.

Unusual styles of the proposed building result from the process of looking for a new form of ecological building that not only integrates into the surrounding environment but also utilizes solar energy and is earth-sheltered to increase protection from unfavorable weather. The first form proposed was inspired by the low-to-the-ground, rural buildings traditionally found in the region of Hana. The shape of the solar eclipse served as inspiration for the curve of the building. The building's ground floor is raised to ensure that it is above flood level. Flexibility, which perceived as beneficial to the ecological concept of the entire them, was stressed when solving the problem of room plan (Figure 6).

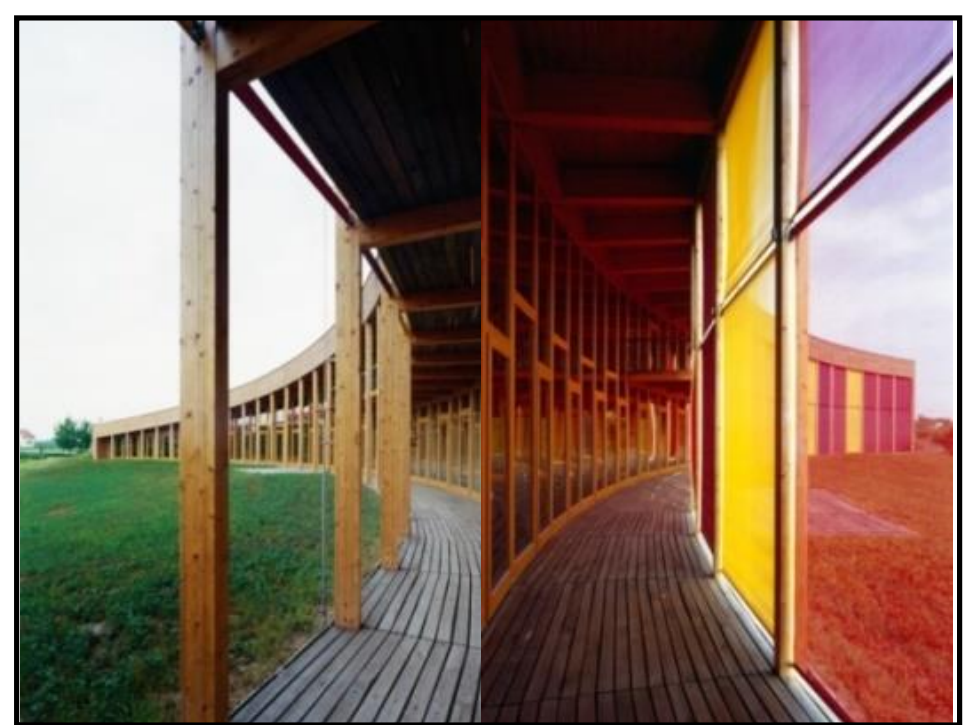

Figure 6. The use of traditional materials in Slunakov Center for Ecological Activities Source:https://www.archdaily.com/29349/slunakov-center-for-ecological-activitiesprojektil-architekti accessed on March 27, 2018

Traditional ingredients used as material and have chosen due to their environmental friendliness. The facade covered with wood, glass, concrete, and stone (stacked). The interior is completed using mainly wood, glass and brick walls plastered or, in the case of unburnt brick, left uncovered. Not only does buildings that have passive building elements (southern glass facades earth shelter on the northern side) that enable the building to save on energy and help the environment, but it also has active measures. These measures, such as heating and ventilation using heat recovery to heat the building, solar collectors for hot water preparation and to support of space heating and earth heat exchanger, are also used for educational and demonstration purposes.

From the two comparative studies, it can conclude that the application of ecological architecture is by utilization of sunlight, wind and surrounding light. The use of natural materials, buildings 
that able to save and create new energy, the shape of it that contextual to the surrounding, the use of green roof and utilization of rainwater. These can also help in applying this theme.

\section{Methodology}

The methodology of this project starts from conducting site selection by literature studies, then the design problem-solving phase, namely by searching ideas, collecting data, literature studies, observation studies, comparative studies. In the final stage, the design stage is carried out by analyzing everything related to the design case.

\section{Results and Discussion}

The building applies the concept of Ecological Architecture, considering the global issues that buildings must have an ecological principle in its design. This issue is related to the increase of global warming so the utilization of energy-efficient and environmentally friendly buildings must be applied to every them today.

\section{Circulation Concept}

In addition, the location is next to Medan Fair Plaza so the building must be integrated by Medan Fair Plaza. Aligning the entrance, exit lanes and the bridges from Medan Fair Plaza to the building is the way to connect this building with the Medan Fair Plaza (Figure 7).

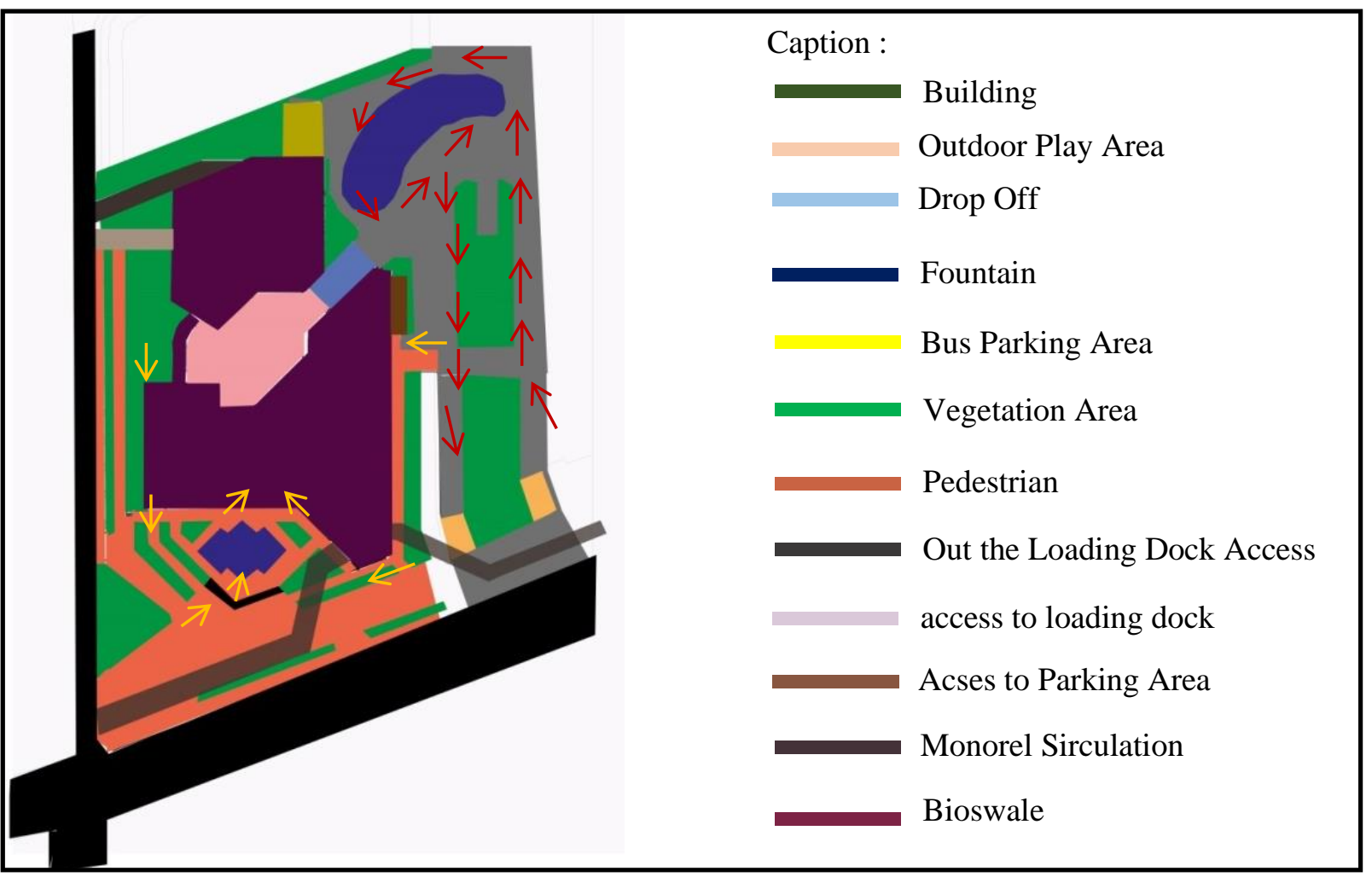

Figure 7. Circulation Concept 


\section{Mass Concept}

This building located on a street corner which is the potential of this site. This location affects the formation of the building mass to maximize the surrounding view (Figure 8).

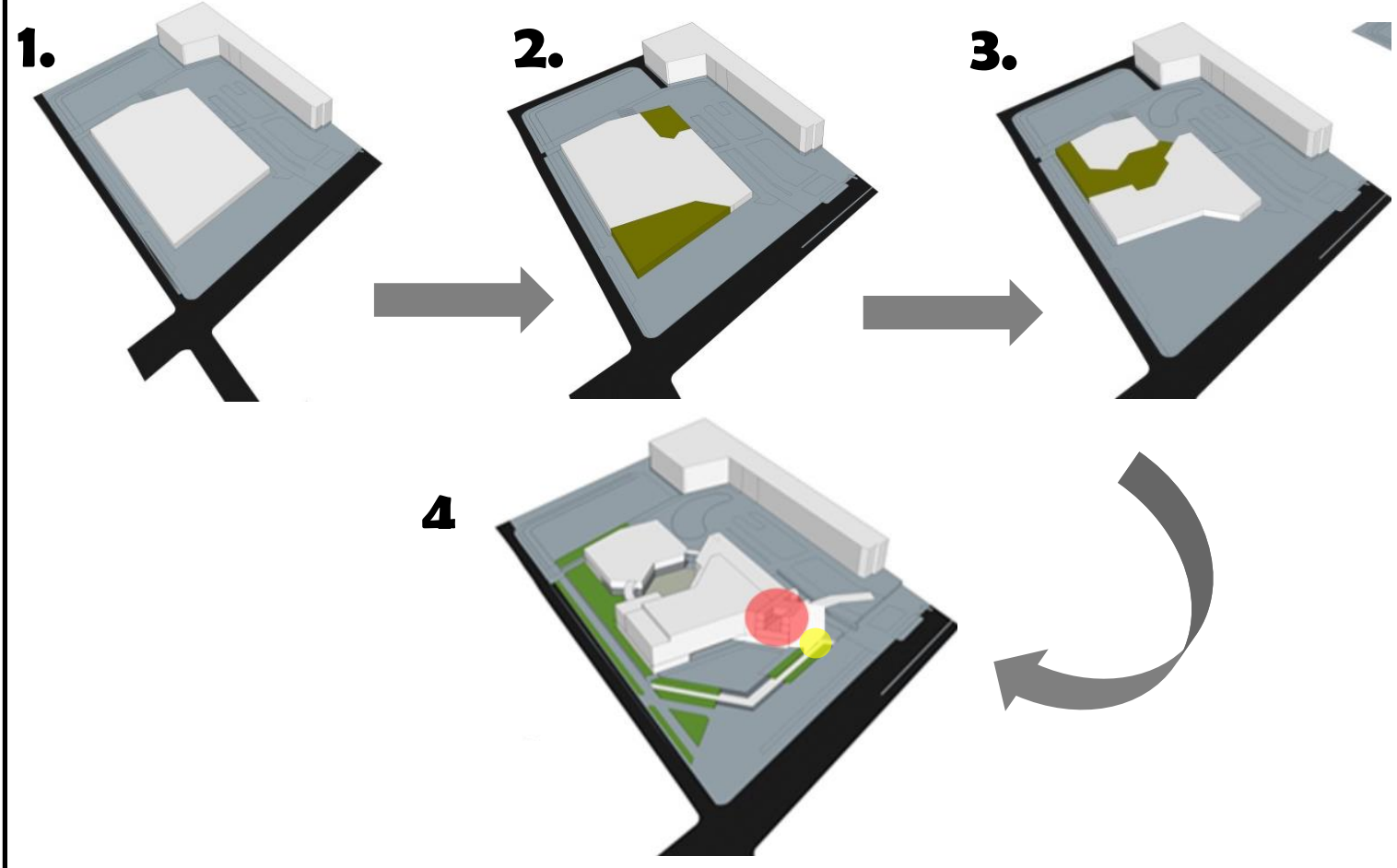

Caption :

1. The mass form is placed far from the road to reduce noise, and at the front, it functions as a public space area so that the building looks magnificent

2. The back and the front part of the building (green) removed from the building mass. On the back,an area will be used as a drop off area. While on the front will be used as an entrance for pedestrians. The corner that protrudes forward serves to respond to the street corner and as a point of view of this building,

3. The center is removed (green) on the building mass. So it becomes separate. This area will function as a park and area of air circulation. This park will also add coolness to the building. While in the West, the mass of the building was reduced and functioned as a flower garden. It aims to respond to the view that is in the North.

4. The building elevated to 2 story and 4 story buildings. Whereas in the corner of the building (third floor) is functioned as a monorail circulation (red). And each mass is connected by a bridge. Not only that on the first floor (Yellow) is used to a tunnel area which functions as access from across the road 


\section{Energy Utilization Concept}

The ecological concept applied in this building by using solar panels as additional energy and also reuses of rainwater for building purposes. The use of air conditioning minimized inside this building, namely by utilizing the air and exhaust fan as a building cooler (Figure 9).

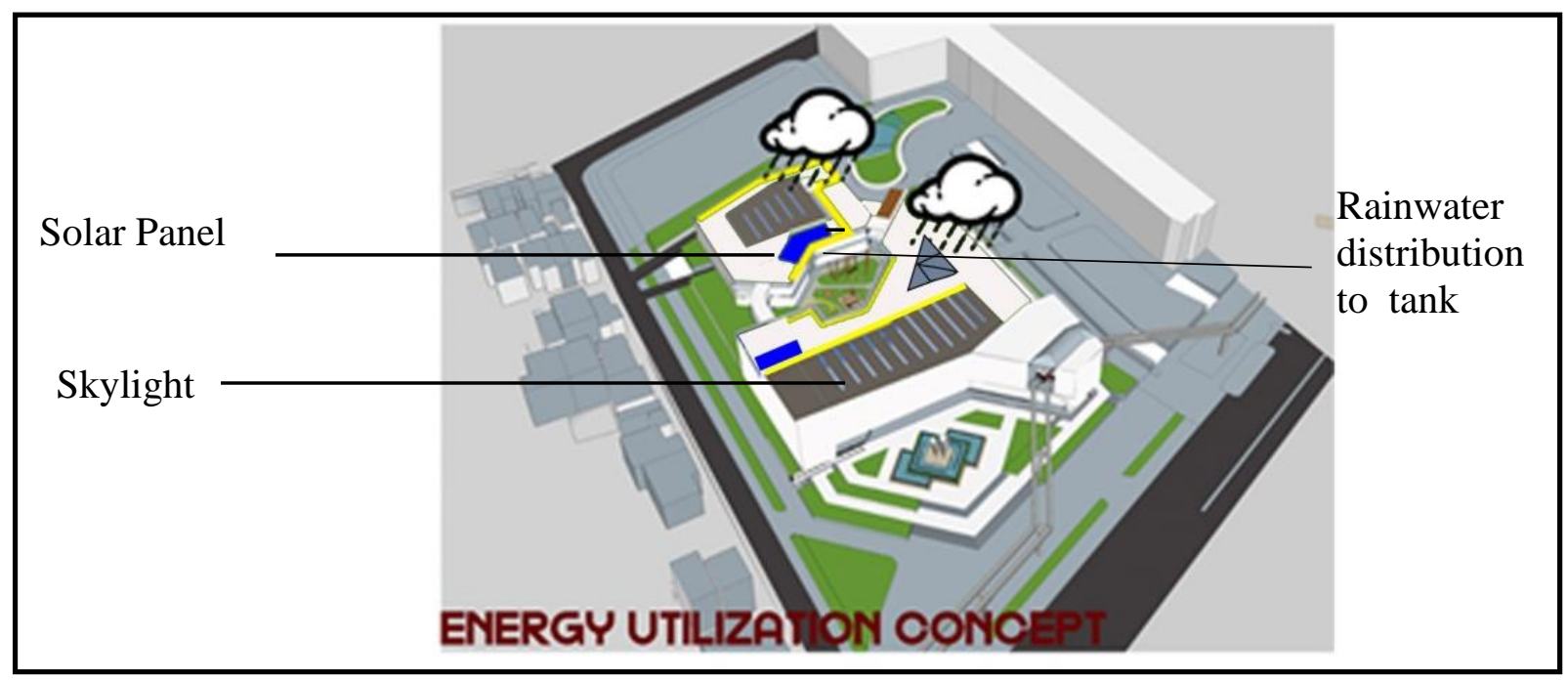

Figure 9. Energy Utilization Concept

This site elevation is useful as a drop-off area for buildings; it also functions as making site cooler than around it. This building also utilizes air circulation as conditioning from this building. Where it is designed to separate, and there is a park in the middle of the building that serves as a place for air circulation. It also supports the ecological principle of this building. The secondary skin as a facade used in it functioning to minimize excessive light into the building; this hole also serves to allow air to enter the building it can reduce the use of air conditioning (Figure 10).

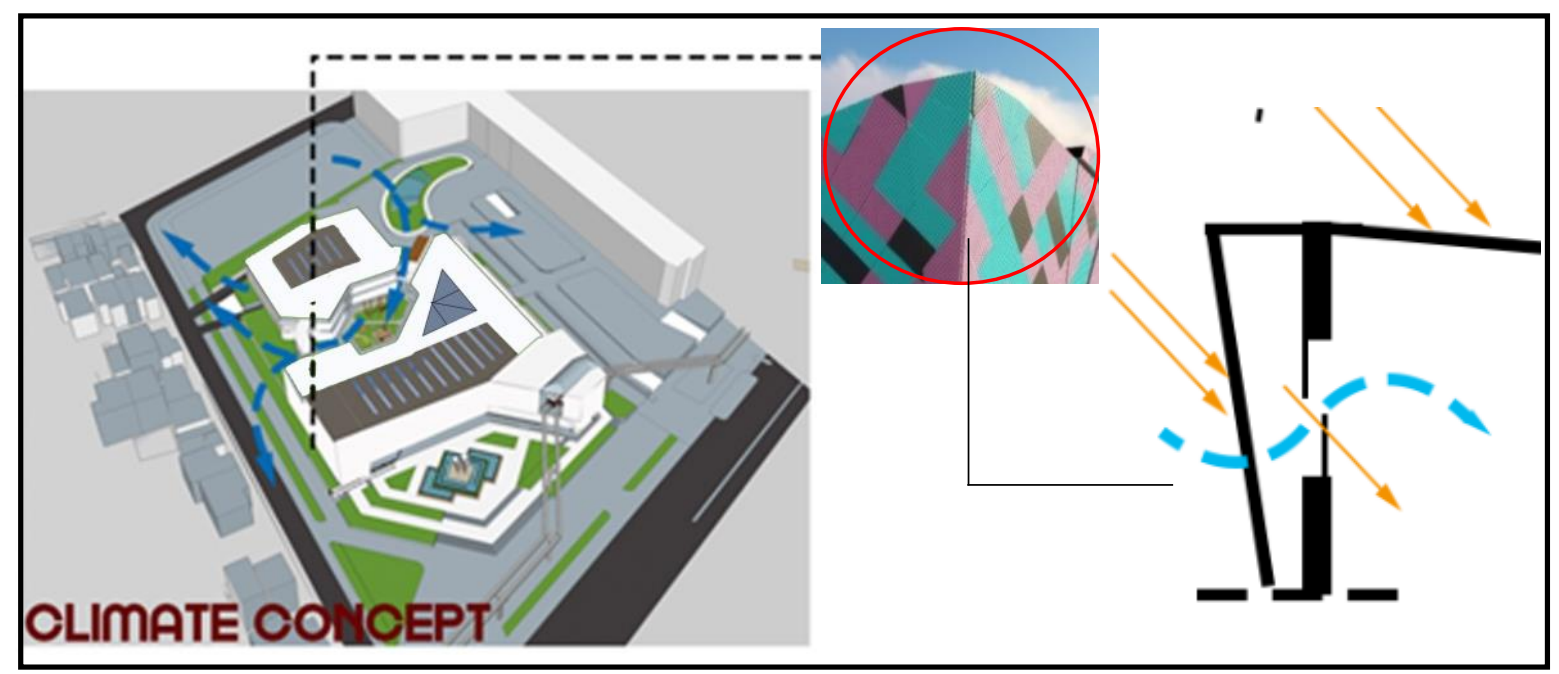

Figure 10. Climate Concept 


\section{Fasade Concept}

The facade of the building inspired by the traditional game pattern of chess karo. A random pattern inspired by one of the chess pieces, the minister. In addition to using it, the use of attractive colors is applied to the facade to attract the attention of visitors, especially children. Colors arranged into irregular patterns according to the character of an unstable child. In addition to not being monotonous (Figure 11).

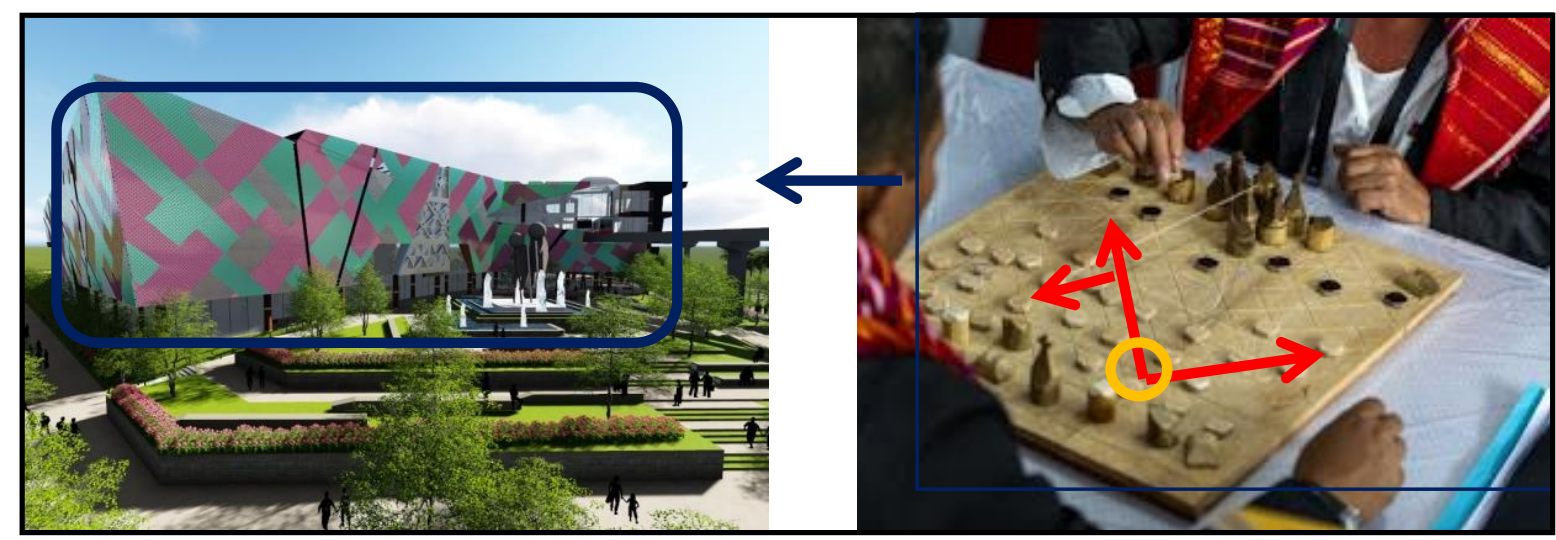

Figure 11. Fasade Concept

\section{Activity Concept}

In this project, the zoning division based on the Tringa Perguruan Taman Siswa concept includes: The first is getting to know (Gallery), The second is understanding (Workshop), The third is to do (Play Area) [5]. This concept used as the basis for the sequence of visitors. In the exhibition area, visitors will be invited to get to know the kind of traditional games. During the training phase, visitors will be taught to create something which made from bamboo, paper, plastic, and casts. While playing, visitors will be free to choose and try the game they want to try (Figure 12).

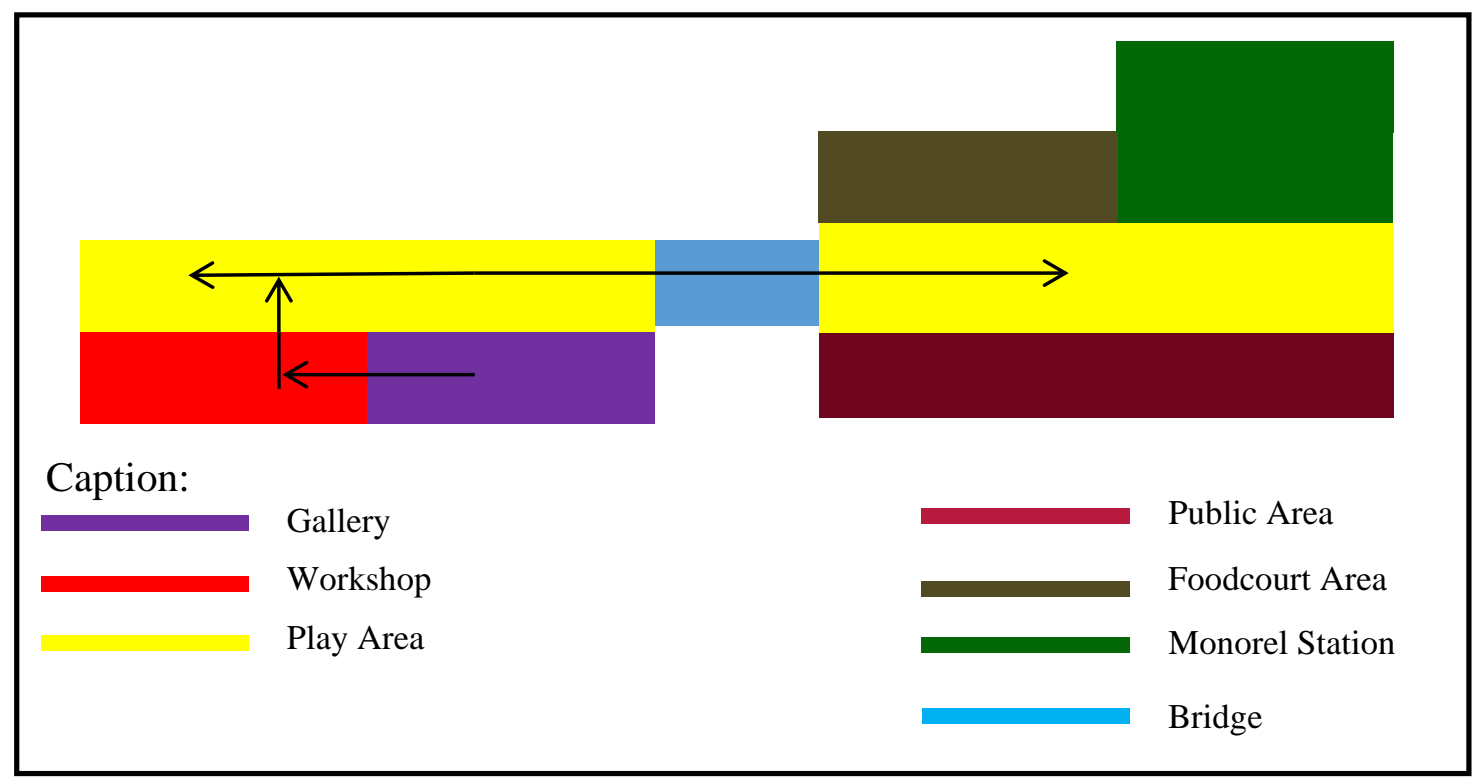

Figure 12. Activity Concept 


\section{Conclusion}

The design of the Children's Creative Center in Medan is a recreational facility that aims to introduce traditional games, especially the North Sumatra games. Presenting a space that can attract children's interest by choosing colors and shapes based on their age and character. Additionally, Presenting it that is relevant to the function of the project and children nowadays but still does not eliminate the atmosphere and characteristics of its culture. In the implementation of the ecological concept is presented with the use of secondary skins to minimize the use of air conditioning and also the use of the void so that light can get into the building. This project is also expected to educate tourists from Medan and tourists that visiting Medan.

\section{Acknowledgment}

This researchers have prepared this article and was partly funded by the Department of Architecture Universitas Sumatera Utara as a contribution to the city government in planning and design to maintain existing local wisdom.

\section{REFERENCES}

[1] S. Munandar, Pengembangan kreativitas anak berbakat, Jakarta: PT. Rineka Cipta dan Dep. Pendidikan dan Kebudayaan, 2009.

[2] V. Metallinou, "Ecological Property and Architecture," Eco-Architecture: Harmonisation between Architecture and Nature, vol. 86, pp. 15-22, 2006.

[3] H. Frick dan F. Suskiyanto, Dasar-dasar Eko-Arsitektur, Yogyakarta: Kanisius, 1998.

[4] A. Y. Permana, "Penerapan Konsep Perancangan Smart Village Sebagai Local Genius Arsitektur Nusantara," Jurnal Arsitektur Komposisi, vol. 9, no. 1, pp. 24-33, 2011.

[5] S. L. Kwary, "Fasilitas Rekreasi Edukatif Permainan Tradisional Jawa di Daerah Istimewa Yogyakarta," Dimensi Arsitektur Petra, vol. 1, no. 2, pp. 125-132, 2013. 